\title{
SLC2A3 wt Allele
}

National Cancer Institute

\section{Source}

National Cancer Institute. SLC2A3 wt Allele. NCI Thesaurus. Code C115021.

Human SLC2A3 wild-type allele is located in the vicinity of 12 p13.3 and is approximately

$17 \mathrm{~kb}$ in length. This allele, which encodes solute carrier family 2 , facilitated glucose transporter member 3 protein, is involved in glucose transport. 